\title{
Deformation of the Macumber Formation, Antigonish Basin, Nova Scotia: implications for the Ainslie Detachment
}

\author{
D.B. Thomas ${ }^{1}$, R.D. NanCE ${ }^{1 *}$ and J.B. MurPhy ${ }^{2}$ \\ 1. Department of Geological Sciences, Ohio University, Athens, Ohio 45701, U.S.A. \\ 2. Department of Earth Sciences, St. Francis Xavier University, Antigonish, Nova Scotia, B2G 2W5, Canada \\ ${ }^{*}$ Corresponding author \\ \Present address: 855 Newcombe Street, Lakewood, CO 80215, U.S.A. \\ Date received:March 28, 2002 I Date accepted:January 31, 2003
}

\begin{abstract}
The Antigonish Basin is one of several Carboniferous structural basins in northeastern Nova Scotia, the evolution of which have been cited as evidence for major detachment faulting within the Viséan Windsor Group of Maritime Canada. Evidence of extension in the Antigonish Basin takes the form of a major subhorizontal structure that closely follows the basin margins and has been interpreted as part of the regional Ainslie Detachment. Placed at the top of the basal Macumber Formation and reportedly characterized by several metres of calc-mylonite, the detachment is considered to have accommodated $10-25 \mathrm{~km}$ of westward transport of the evaporitic Windsor and overlying Mabou groups during the late Namurian-early Westphalian.

However, deformation within the Macumber Formation limestone immediately beneath the detachment surface suggests local extension of Viséan age. Recumbent intraformational folds are overlain by depositional breccias that contain previously folded fragments and are themselves recumbently folded. These relationships suggest repeated movement that began soon after limestone deposition. Furthermore, fold asymmetry and the orientation of calcite veins and small-scale normal faults suggest variable directions of extension that converge on the centre of the basin located in St. Georges Bay. While these data do not preclude the existence of the Ainslie Detachment, they suggest that the Macumber Formation in the Antigonish Basin records an earlier episode of deformation that occurred in response to local gravity sliding rather than to movement on a regional detachment surface.
\end{abstract}

\section{RESUMÉ}

Le bassin d'Antigonish constitue l'un d'une série de bassins structuraux du Carbonifère dans le nord-ouest de la Nouvelle-Écosse dont l'évolution a été citée comme preuve d'une dislocation importante par détachement à l'intérieur du groupe viséen de Windsor dans les provinces Maritimes. On relève une preuve du prolongement dans le bassin d'Antigonish sous la forme d'une structure subhorizontale importante qui suit de près les limites du bassin et qui a été interprétée comme une partie du détachement régional d'Ainslie. On estime que le détachement, situé au sommet de la Formation basale de Macumber et caractérisé, d'après ce qu'on dit, par plusieurs mètres de mylonite calcique, a permis le transport vers l'ouest sur dix à 25 kilomètres des groupes sus-jacent de Mabou et évaporitique de Windsor au cours de la période du Namurien tardif-Westphalien précoce.

La déformation à l'intérieur du calcaire de la Formation de Macumber immédiatement au-dessous de la surface du détachement, laisse toutefois supposer un prolongement local à l'époque du Viséen. Les plis intraformationnels couchés sont recouverts de brèches de sédimentation renfermant des fragments antérieurement pliés qui sont eux-mêmes repliés sur un plan axial horizontal. Ces rapports permettent de supposer un mouvement répété qui a débuté peu après la sédimentation du calcaire. De plus, l'asymétrie des plis et l'orientation des filons de calcite et des failles normales de petite échelle laissent supposer des orientations de prolongation variables qui convergent vers le centre du bassin situé dans la baie de St. Georges. Même si ces données n'écartent pas la possibilité de l'existence du détachement d'Ainslie, elles permettent de supposer que la Formation de Macumber dans le bassin d'Antigonish évoque un épisode plus hâtif de déformation, survenu à la suite d'un glissement gravitationnel local plutôt que d'un déplacement à la surface d'un détachement régional.

\section{INTRODUCTION}

Nova Scotia is home to several late Devonian-Carboniferous sedimentary basins, the genesis and development of which have been the subject of controversy. The Antigonish Basin, located in northeastern Nova Scotia (Fig. 1), is one of these basins and contains more than $6500 \mathrm{~m}$ of sedimentary rocks of Late Devonian to Late Carboniferous age (Boehner and Giles 1993). The basin fill unconformably overlies Neoproterozoic to Devonian basement lithologies of the Avalon terrane in the Antigonish Highlands to the west (e.g., Murphy et al. 1991), and is bounded onshore by the Morristown Fault to the north and by the Glenroy Fault to the south. To the northeast it is hidden beneath St. Georges Bay, on the north and eastern sides of which it is bordered by the Hollow Fault Zone and the Judique Fault, respectively.

The Antigonish Basin is located on the south-central margin of the larger Maritimes Basin (inset, Fig. 1), which consists of several depocentres that developed during the waning stages of 
the Acadian Orogeny (e.g., McCutcheon and Robinson 1987). Following Bradley (1982), the Antigonish Basin has traditionally been interpreted as a pull-apart structure that formed as a result of Alleghanian strike-slip faulting (Boehner and Giles 1982; Stockmal et al. 1986). On Cape Breton Island, however, sedimentological studies of broadly coeval basins suggest that they opened as a series of half-grabens (Hamblin and Rust 1989). More recently, Lynch and Tremblay (1994) have proposed that the basin evolved above a regional detachment fault (Margaree Shear Zone) that formed as a result of orogenic collapse following Acadian crustal thickening in the Devonian.

Following Fyson (1967), Lynch and Tremblay (1994) further proposed that extensional deformation within the Maritimes Basin is not limited to the Margaree Shear Zone, but reoccurred during the late Namurian-early Westphalian with the development of a regional flat-lying extensional fault (the Ainslie Detachment) that developed within the basin fill. Located near the base of an evaporitic sequence of Viséan age (Windsor Group) and distributed across $10,000 \mathrm{~km}^{2}$, the detachment surface is held to be responsible for as much as $2 \mathrm{~km}$ of stratigraphic omission and 10-25 km of westward displacement (Lynch and Giles 1995). The detachment is placed at the top of the basal limestone of the Macumber Formation, the rheological contrast between the limestone and overlying evaporitic sequence acting as a stratigraphically controlled zone of weakness.

In this study, we examine the deformation of the Macumber Formation in the Antigonish Basin in an attempt to determine its relationship to the Ainslie Detachment. The data suggest that deformation took place soon after deposition of the formation and occurred in response to repeated movement directed towards the centre of the basin located in St. Georges Bay. We therefore conclude that deformation of the Macumber Formation in the Antigonish Basin predated the Ainslie Detachment and was the result of local gravity sliding rather than major regional detachment faulting.

\section{GEOLOGY OF THE ANTIGONISH BASIN}

\section{Basin Stratigraphy}

The stratigraphy and surface geology of the Antigonish Basin have been mapped in some detail by Boehner and Giles (1982), and geophysical data have provided constraints on its subsurface and offshore geology (Durling et al. 1995a, b). The onshore geology of the Antigonish Basin (Fig. 2) and the stratigraphy of the basin fill (Fig. 3) involve units of the Horton, Windsor, Mabou, and Cumberland groups.

Horton Group: The oldest sedimentary rocks of the Antigonish Basin are late Devonian-early Carboniferous terrestrial formations of the Horton Group, which vary greatly in thickness and rest with regional unconformity on Avalonian basement lithologies. Predominantly consisting of sandstone and conglomerate, but including shale and minor algal and oolitic limestone in the uppermost Wilkie Brook Formation, the Horton Group is interpreted as comprising alluvial fan, braided fluvial, and lacustrine

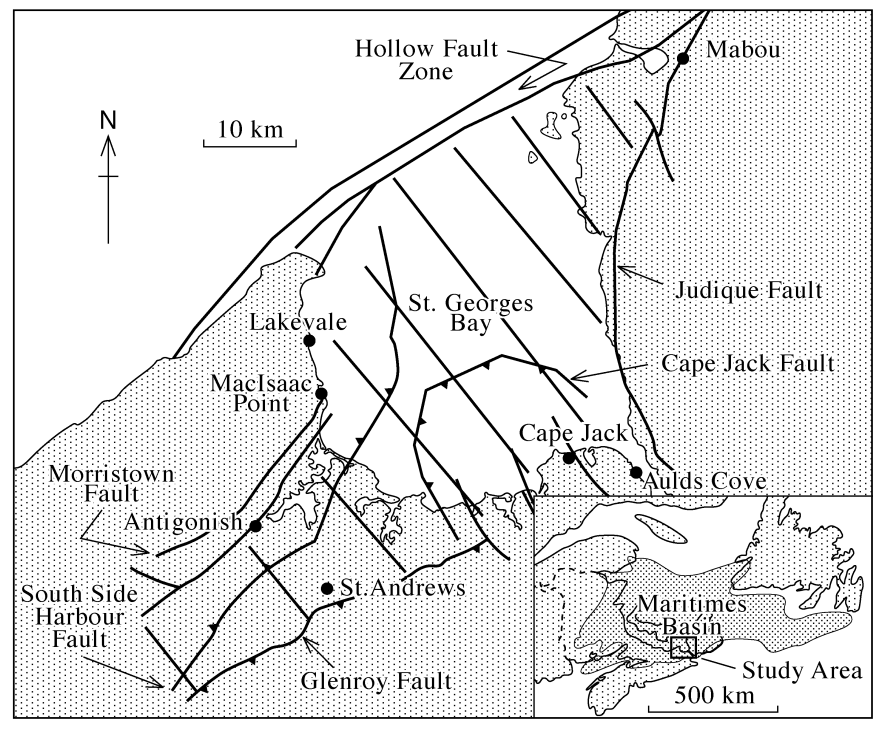

FIG. 1 Major internal and bounding faults of the Antigonish Basin, Nova Scotia and location of key field sites described in this study (base map modified from Durling et al. 1995a). Inset shows location of area relative to the larger Maritimes Basin of Atlantic Canada (from McCutcheon and Robinson 1987).

units deposited during the initial opening of the Maritimes Basin (e.g., McCutcheon and Robinson 1987).

Windsor Group: An angular unconformity separates the Horton Group from the overlying Windsor Group, which varies from a few meters to more than $1500 \mathrm{~m}$ in thickness and contains fossils of Viséan age (Boehner and Giles 1982). The Windsor Group is the only marine assemblage in the Antigonish Basin (Giles 1981) and is floored by limestone of the Macumber Formation that rims the basin margin (Fig. 2). The Macumber Formation limestone varies in thickness from 3 to $25 \mathrm{~m}$ and is finely laminated on a 1-10 mm scale at its base. Basal laminated sections range in thickness from a few centimetres to a metre, and are commonly overlain by brecciated horizons. The Macumber Formation is considered mid-Viséan in age (Arundian-Holkerian; Utting et al. 1989) and is interpreted as having been deposited in a subtidal sabkha environment in response to a rapid transgressive event (Schenk 1967; Boehner and Giles 1993). Evidence of deformation in the Macumber Formation occurs in the form of folding, particularly on the western flank of the basin at MacIsaacs Point and Lakevale (Fig. 1).

The Macumber Formation is locally overlain by limestone of the Gays River Formation but is more usually succeeded by the evaporitic Bridgeville and Hartshorn formations consisting of halite, gypsum, and anhydrite with thin interbeds of limestone and siltstone. Both formations are interpreted as documenting a marine basinal setting (Boehner and Giles 1993).

The overlying Lakevale Formation consists of grey to reddish-brown polymictic conglomerate and paraconglomerate with gypsum and anhydrite in the subsurface. It is overlain by the Wallace Brook and Addington formations, which comprise interbedded limestone, anhydrite, siltstone, and shale that have 


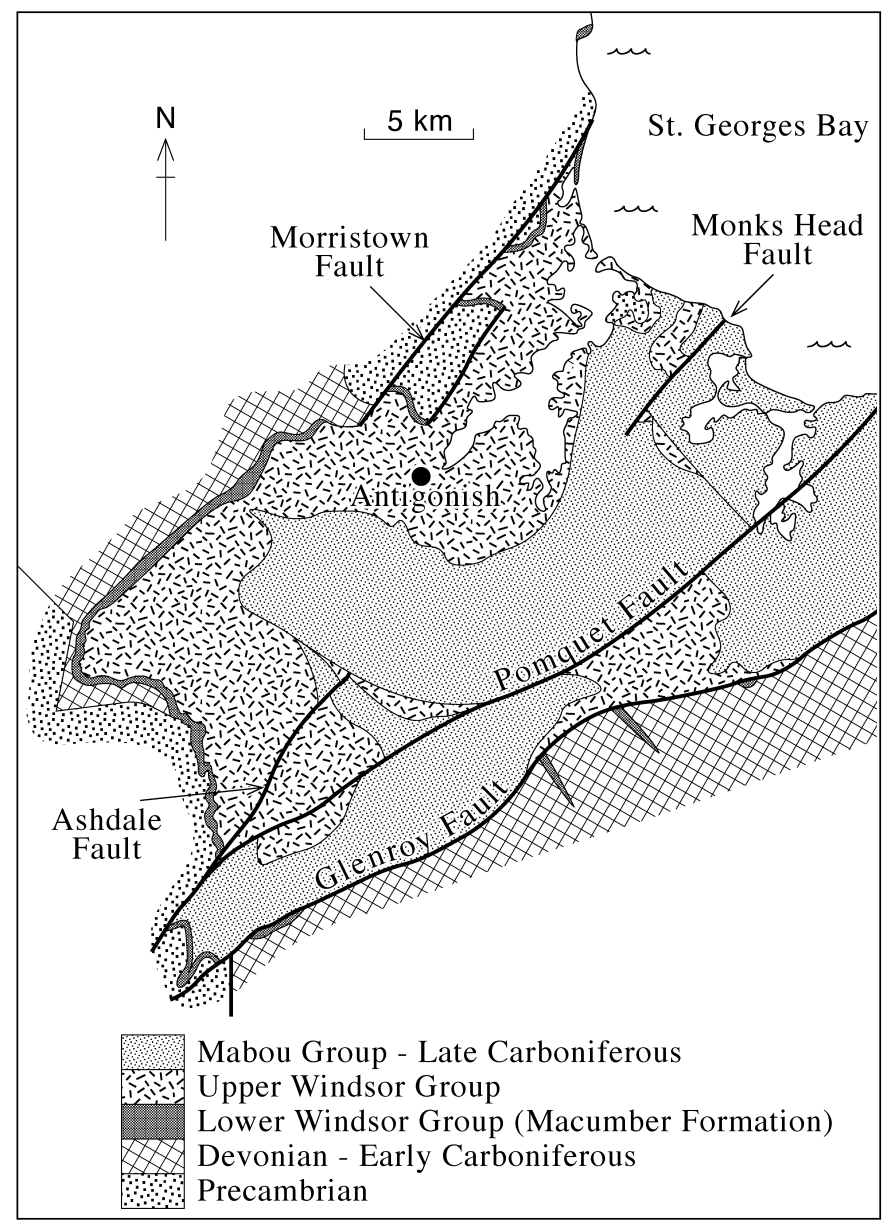

FIG. 2 Simplified geological map of the Antigonish Basin (modified from Boehner and Giles 1982).

been interpreted as recording a series of transgressive-regressive events (Boehner and Giles 1993).

The uppermost unit of the Windsor Group, the Hood Island Formation, is separated from units below by a disconformity. It contains red siltstone and sandstone, beds of marine limestone and dolostone, and minor amounts of gypsum that are thought to be the product of deposition in a sabkha environment (Boehner and Giles 1993). The formation is nearly $900 \mathrm{~m}$ thick and is widely distributed throughout the basin.

Mabou Group: Late Carboniferous sedimentation began with the Namurian Mabou Group, which conformably overlies the Windsor Group and consists of two terrestrial sequences, the Hastings and Pomquet formations, that total $4700 \mathrm{~m}$ in thickness. The Hastings Formation comprises shale, siltstone, and minor limestone of probable lacustrine origin, whereas the Pomquet Formation comprises siltstone and sandstone and is exclusively fluvial (Boehner and Giles 1993).

Cumberland Group: The youngest unit exposed in the Antigonish Basin is the Port Hood Formation of the Westphalian Cumberland Group. The formation is $400 \mathrm{~m}$ thick and contains grey and brown sandstone and conglomerate of fluvial origin (Boehner and Giles 1993).

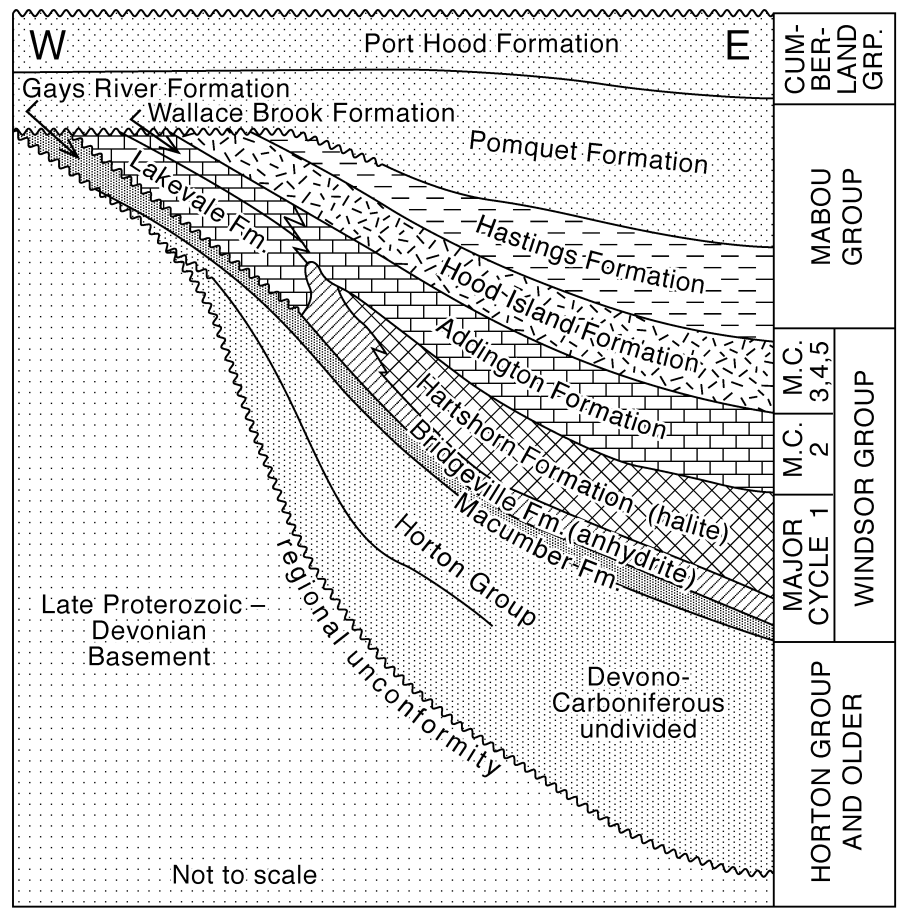

FIG. 3 Diagrammatic representation of major stratigraphic relationships within the Antigonish Basin (after Boehner and Giles 1982).

\section{Ainslie Detachment}

In the course of mapping the Antigonish Basin, Boehner and Giles (1982) identified a major subhorizontal fault which they termed the Antigonish Thrust. This low-angle structure was interpreted as recording reverse movement and was placed within the evaporite sequence at the base of the Windsor Group. Boehner and Giles (1982) attributed all major folds and a number of faults in the basin to movement on this thrust surface, but the magnitude of movement remained uncertain due to a lack of displacement markers. The thrust was mapped as terminating to the southeast in the subsurface against the Glenroy Fault.

However, what Boehner and Giles (1982) mapped as a thrust, Lynch and Giles (1995) reinterpreted as part of a regional flat-lying extensional fault (Ainslie Detachment) that they held to be responsible for up to $2 \mathrm{~km}$ of local stratigraphic omission in the Windsor Group. The detachment closely follows the margins of the basin, which they considered to represent an erosional remnant of a large synclinal structure in the detachment surface. Lynch and Giles (1995) placed the detachment along a low-strength carbonate-evaporite interface at the top of the Macumber Formation where they reported a 3-10 m zone of calc-mylonite and deformed limestone in contact with the base of the Windsor Group evaporite sequence. The calc-mylonite was described as showing a strongly laminated fabric, grain-size reduction of recrystallized layers, porphyroclasts suggesting bed-parallel shear, and folding of laminae. Movement on the detachment surface, which locally juxtaposes the Namurian Mabou Group against the Macumber Formation and is unconformably overlain by Westphalian C clastic rocks of 


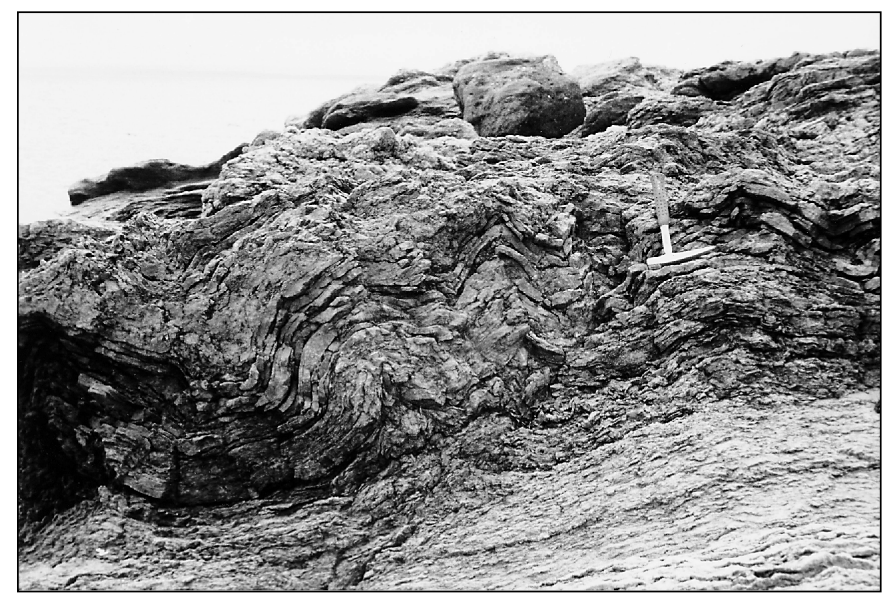

(a)

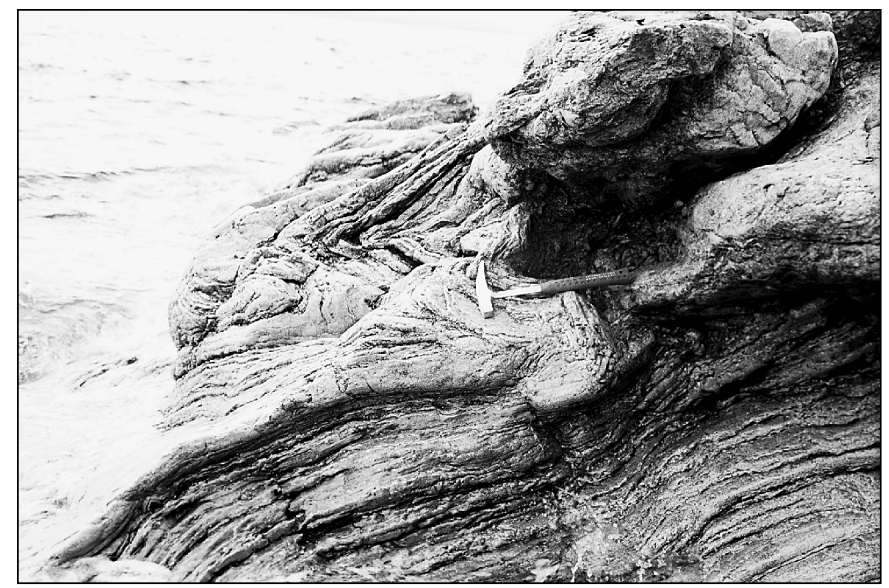

(b)

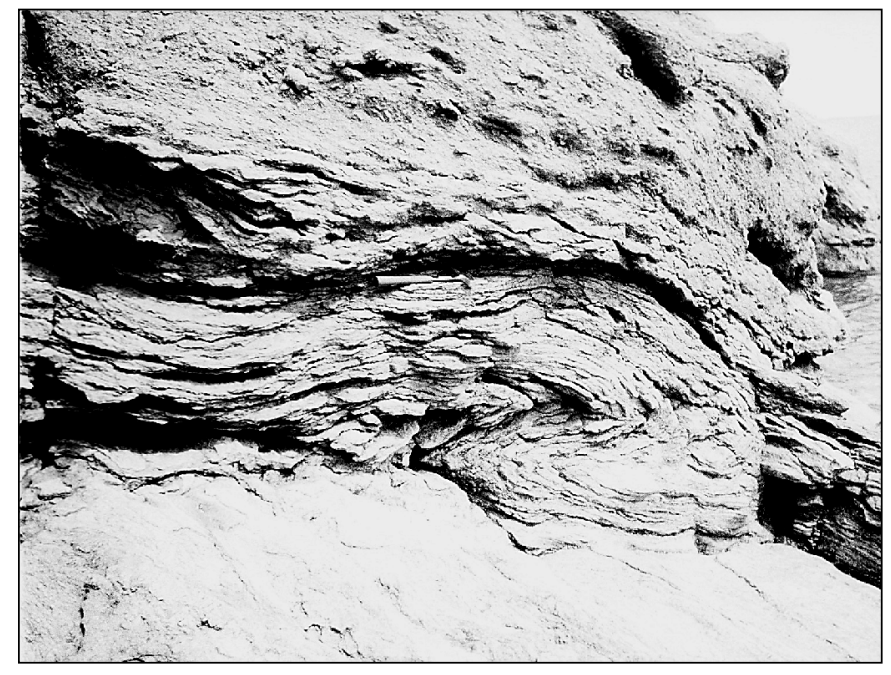

(c)

FIG. 4 Folding in Macumber Formation limestone at MacIsaacs Point. (a) Inclined train of buckle folds illustrating fold style. (b) and (c) Recumbent folds overlying thinly laminated horizon at base offormation. the Cumberland Group, is considered to have occurred in the late Namurian to early Westphalian. Stratigraphic evidence that supports significant basin deepening following the Viséan was attributed to this movement.

\section{STRUCTURE OF THE MACUMBER FORMATION}

To determine whether the deformation of the Macumber Formation reflects movement on the overlying Ainslie Detachment, detailed analyses of small-scale structures developed within the Macumber Formation were made at key sites identified from the existing literature. They included outcrops at MacIsaacs Point, Lakevale, Cape Jack, Aulds Cove, and along the western basin margin (Figs. 1 and 2).

\section{STRUCTURAL FEATURES}

A variety of structures within the Macumber Formation suggest that it records repeated episodes of deformation that began soon after its deposition. These structures include recumbent folds, breccia zones, extension veins, and normal faults, and occur at all sites exposing the Macumber Formation limestone.

MacIsaacs Point: At MacIsaacs Point on the west side of St. Georges Bay (Fig. 1), steep cliffs expose basement, Macumber Formation limestone, and Windsor Group evaporites. The limestone beds are highly deformed with inclined to recumbent buckle folds discordantly overlying an unfolded but finely laminated horizon at the base of the formation (Fig. $4 a-c)$. The folds show broadly parallel geometry and have amplitudes that increase from 2-3 cm near the base of the deformed zone to $40-50 \mathrm{~cm}$ up section. The predominant sense of vergence throughout the deformed zone is eastward (seaward); all of the largest folds being consistent with a down-dip (due east) sense of movement (Fig. 5). However, westward-verging folds also occur; the consistent N-S orientation of their fold axes, coupled with the variable dip of the fold axial surfaces and the detached style of the folding, suggesting an origin through slumping. Such an origin is supported by the presence of previously folded fragments in overlying breccia units (see below), which requires at least some of the deformation to have been syndepositional with respect to the Windsor Group.

In outcrop, the finely laminated horizon discordantly underlying the folded zone (Fig. 4c) resembles the calc-mylonite described by Lynch and Giles (1995). To test this interpretation, several oriented samples of the horizon were examined in thin section. In the absence of a stretching lineation, the sections were cut north-south, parallel to the direction of movement proposed for the Ainslie Detachment by Lynch and Giles (1995). However, no kinematic indicators were observed and the fabrics were found to be those typical of undeformed algal limestone rather than calc-mylonite.

Directly above and locally truncating the folded interval erosionally, the Macumber Formation contains horizons of intraformational limestone breccia several metres thick that are separated by undisturbed strata. Crudely bedded and almost 


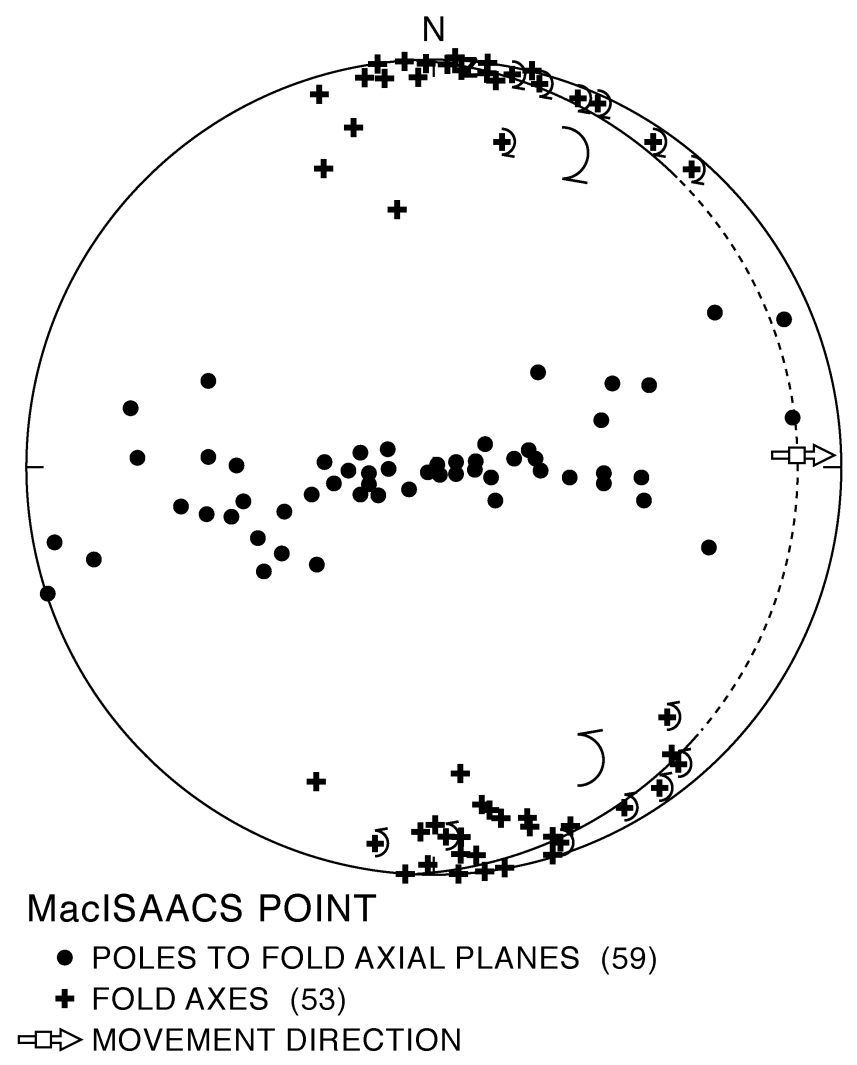

FIG. 5 Equal-area projection showing fold orientations at MacIsaacs Point. Note fold asymmetry (curved arrows) is consistent with eastward-directed movement.

entirely comprised of reworked and corroded (karstified) fragments of Macumber Formation limestone, some of which contain calcite veins (e.g., Keppie et al. 1978), these breccias have been variously attributed to slumping (Lavoie and Sangster 1995), to post-Windsor dissolution (Clifton 1967; Geldsetzer 1978), to syndepositional (Schenk 1984) or post-depositional (Boehner 1980) karstic processes, and to later hydraulic fracturing by hydrothermal fluids (Ravenhurst and Zentilli 1987; Lavoie and Sangster 1995). Their association with zones of folding and their proximity to the carbonate-evaporite interface also suggests a genetic linkage to the Ainslie Detachment (Lynch et al. 1998). Regardless of their origin, however, the breccias exposed at MacIsaacs Point are clearly of depositional origin and, hence, part of the stratigraphy, the repetition of horizons implying that the Macumber Formation limestone experienced repeated episodes of karstification and brecciation prior to the deposition of the overlying evaporitic sequence of the Windsor Group.

Like the underlying Macumber Formation limestone, the breccia horizons are folded (Fig. 6a), and the folds predominantly verge eastward with amplitudes of $40-50 \mathrm{~cm}$. In addition, the layering within individual corroded breccia fragments is buckle folded (Fig. 6b), indicating that some folding pre-dated karstification and, while clearly post-dating lithification, must have been initiated soon after limestone deposition. Folding of the breccia horizons requires a repeated episode of deformation following

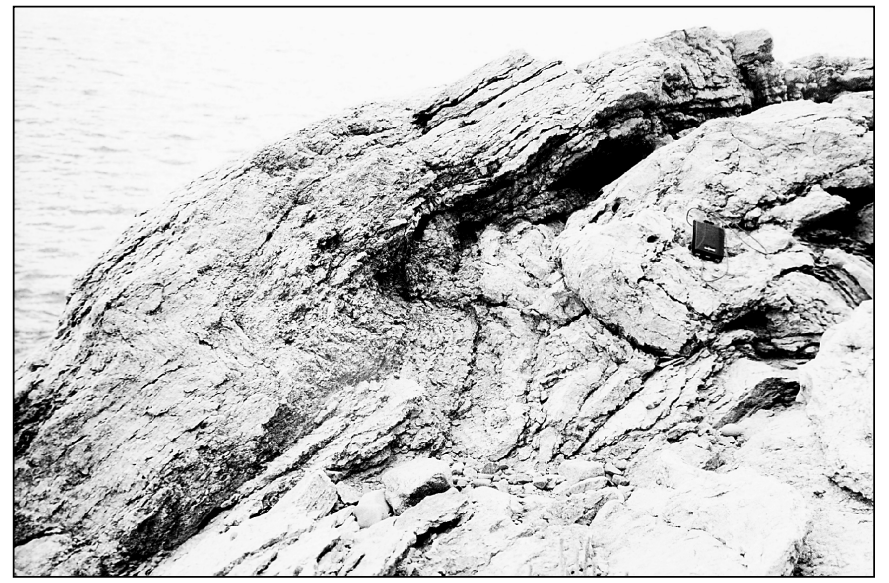

(a)

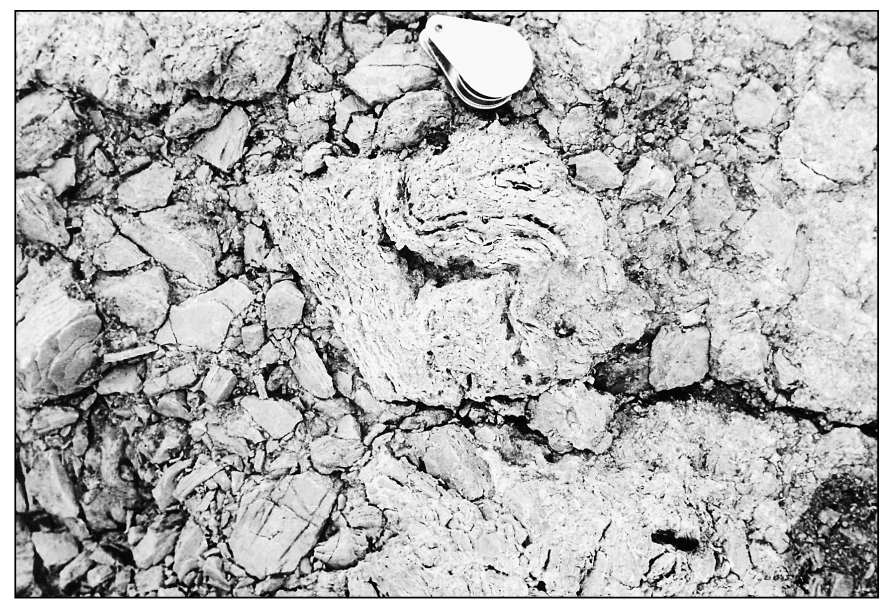

(b)

FIG. 6 Folding in Macumber Formation breccia at MacIsaacs Point. (a) Large, east-verging recumbent fold. (b) Folded layering within individual clast of limestone breccia.

their deposition. Hence, the deformation, karstification, and brecciation are considered penecontemporaneous processes that recurred syndepositionally with respect to the Windsor Group.

Lakevale: North of MacIsaacs Point, the Macumber Formation limestone is again exposed in sea cliffs at Lakevale (Fig. 1). Here, thinly laminated limestone beds developed near the top of the formation contain small calcite crystals and are crenulated about fold axes that plunge gently northeast. These horizons, like those at MacIsaacs Point, closely resemble those interpreted by Lynch and Giles (1995) as calc-mylonite produced during movement of the Ainslie Detachment. In thin sections cut perpendicular to the fold hinges, the calcite crystals are indeed enveloped by the laminations in a manner resembling sigma structures in ductile shear zones (Fig. 7a). However, the crystals are highly angular and do not resemble porphyroclasts, and the apparent sigma structures show no preferred sense of shear. Instead, the subhedral shape of the calcite crystals suggests that they are pseudomorphs after gypsum and that the crystal-laminated interval exhibits a primary fabric that records little post-depositional deformation other than compaction. Similar fabrics enveloping pseudomorphs 


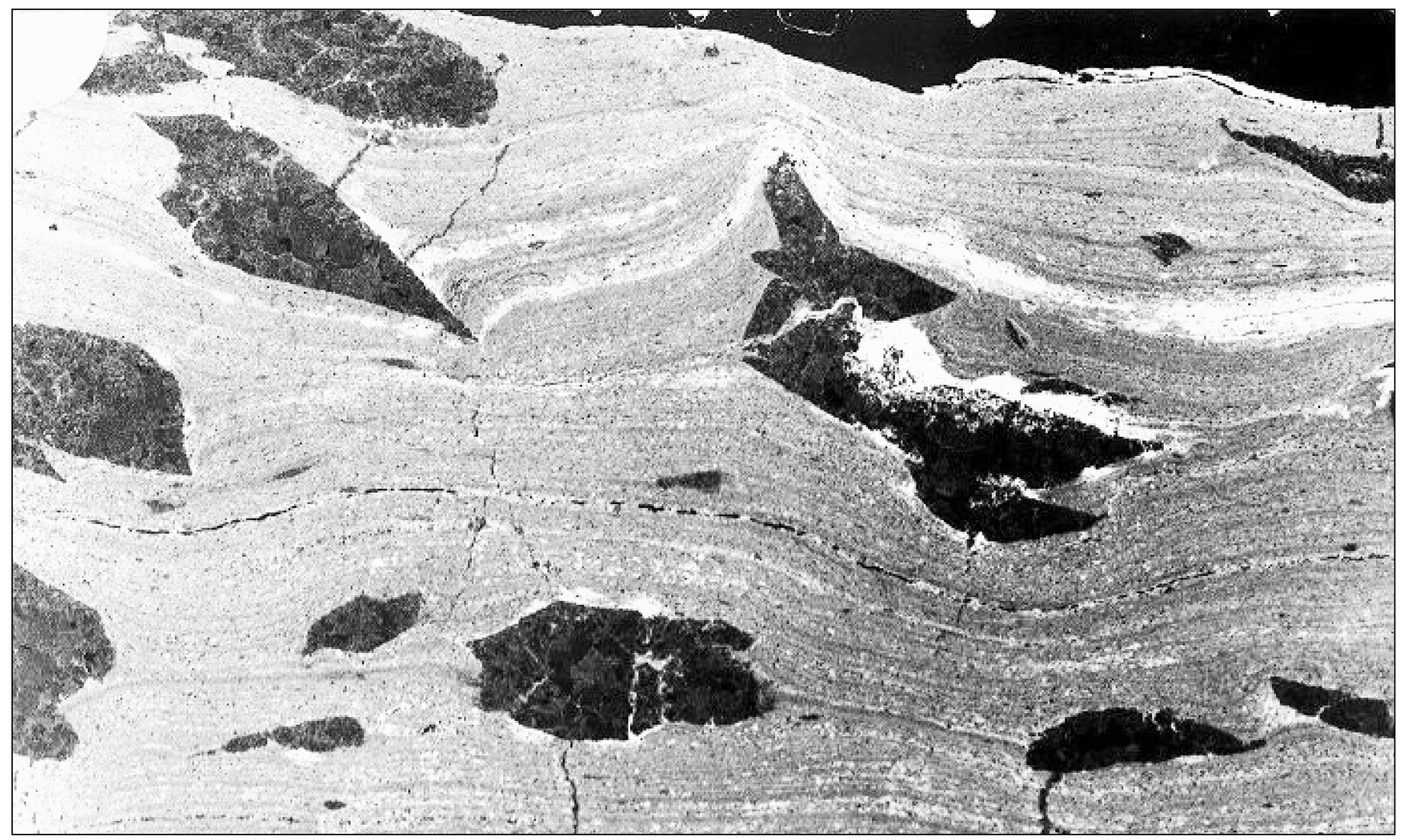

(a)

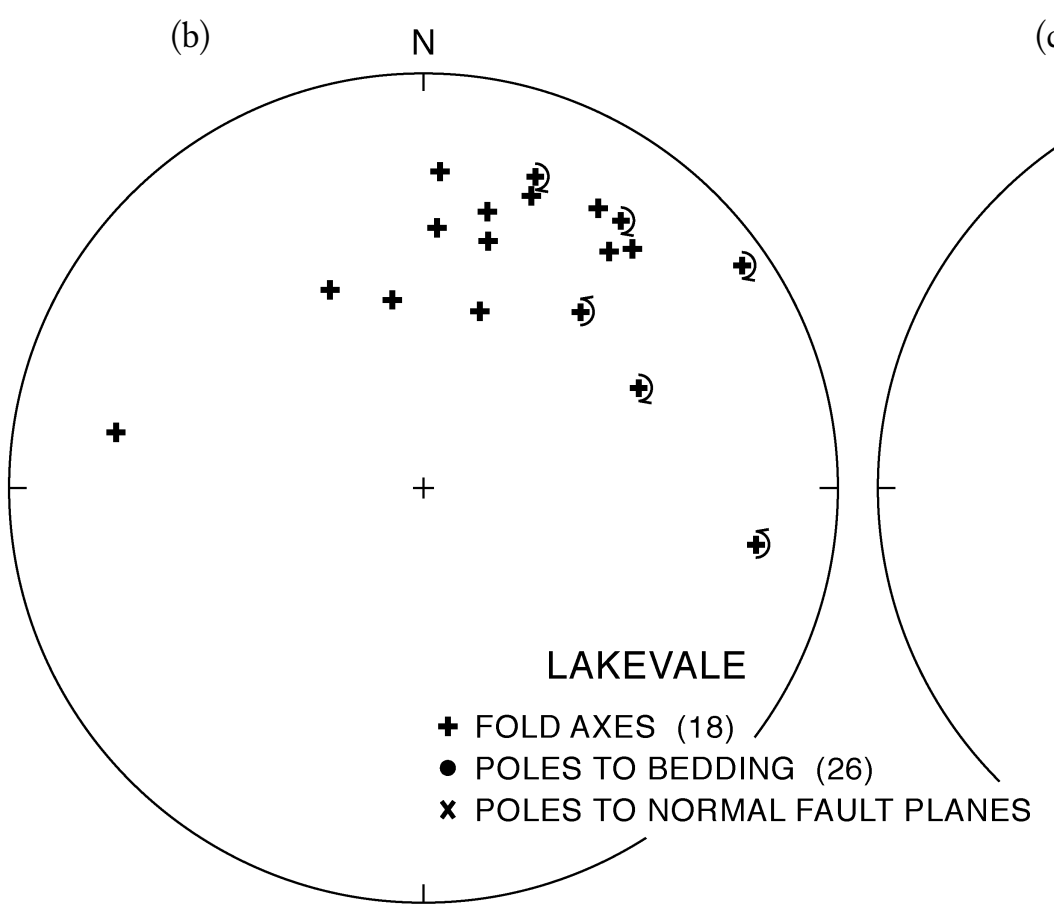

(c)

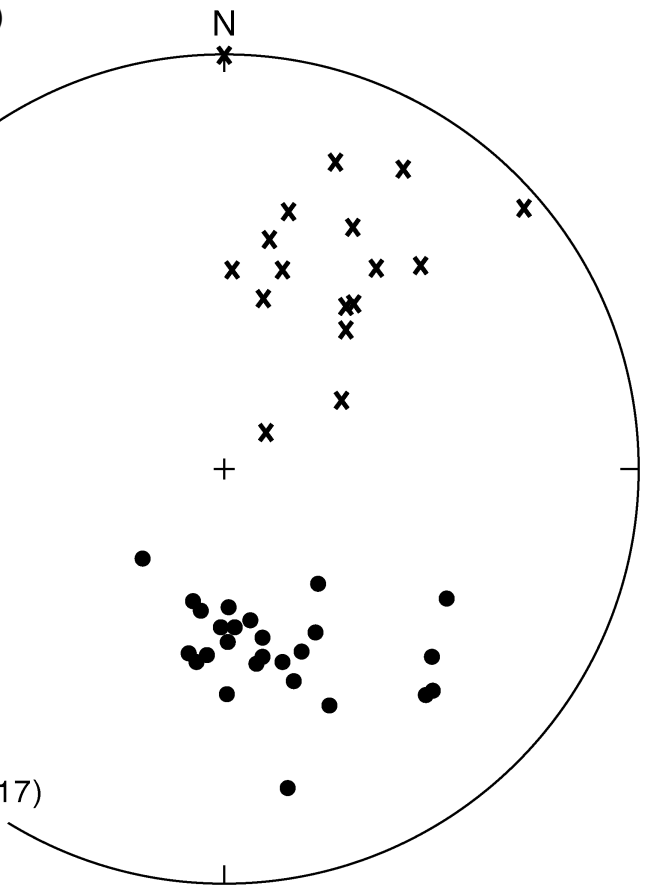

FIG. 7. (a) Thin section negative of Macumber Formation limestone at Lakevale. Angular crystals are interpreted to be calcite pseudomorphs after gypsum, their subhedral form implying little post-depositional deformation. (b) Equal-area projection showing orientation and sense of vergence (curved arrows) of folds at Lakevale. (c) Equal-area projection showing orientation of small-scale normal faults offsetting individual bedding planes at Lakevale. 


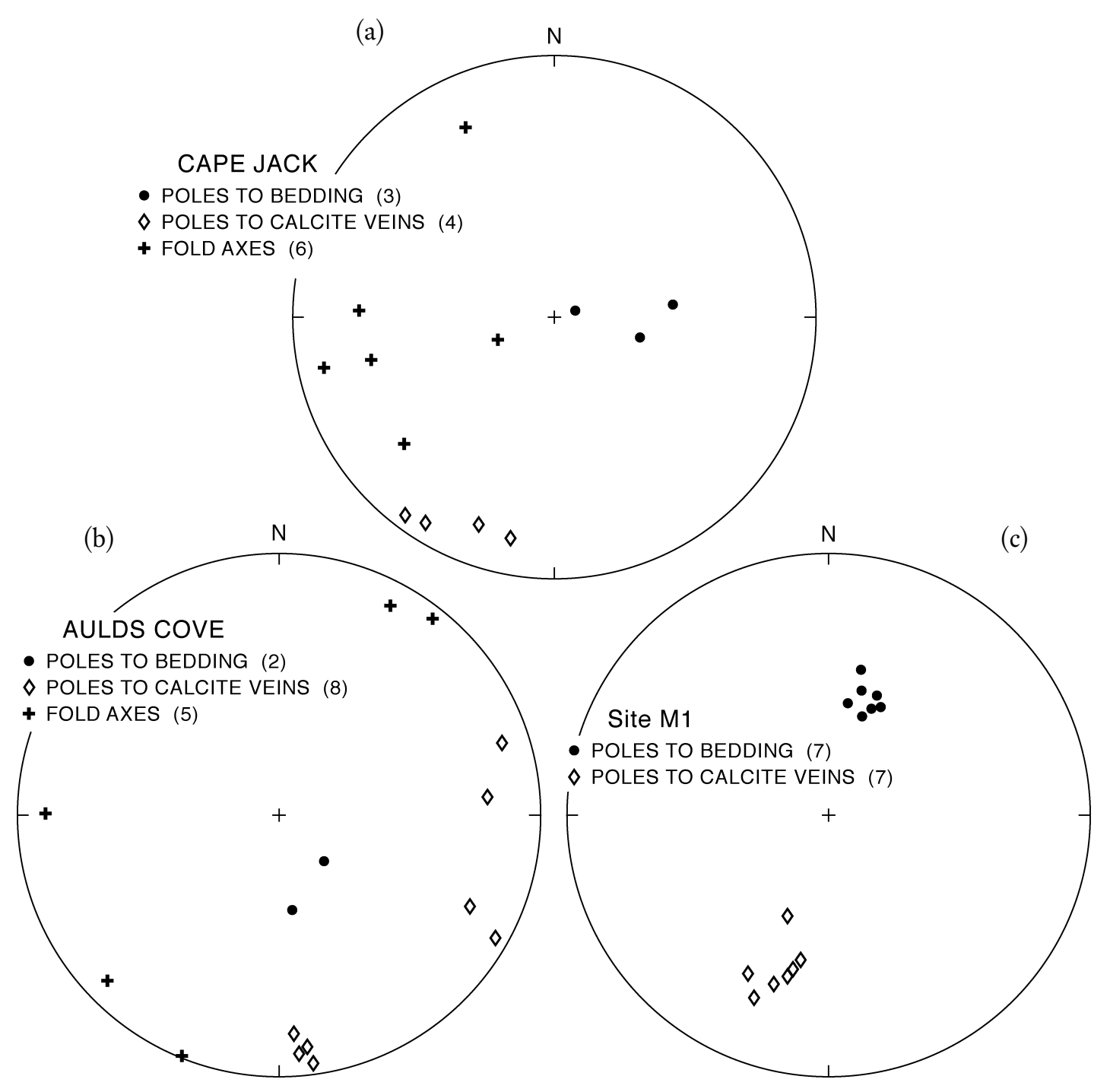

FIG. 8 Equal-area projections showing the orientation of minor structures at (a)Cape Jack, (b)Aulds Cove, and (c) at the western basin margin.

after gypsum have been described from undeformed limestone of the Macumber Formation in Cape Breton Island by Savard et al. (1996).

However, deformation is evident towards the base of the Macumber Formation where a series of large inclined to recumbent folds are developed that resemble the slump structures at MacIsaacs Point. Fold axes plunge generally north-northeast and, where asymmetric, the predominant sense of vergence is again broadly eastward (Fig. 7b). Deformation also occurs in thin limestone beds immediately above the crystal-laminated layer, where it takes the form of boudinage and small-scale normal faults. Although the age of these structures relative to the folds is unknown, their orientations are consistent with broadly NE-SW extension (Fig. 7c).

Cape Jack, Aulds Cove, and Western Basin Margin: Along the coastline at Cape Jack (Fig. 1.), outcrops of the Macumber Formation limestone dip gently westward and contain calcitefilled fractures or veins that dip steeply north-northeast (Fig. 8a), indicating extension in this orientation. As clasts containing similar veins occur in the breccia horizons at MacIsaacs Point, their formation is considered to have been penecontemporaneous with the folding of the Macumber Formation limestone. At Cape Jack, minor symmetrical folds in the bedding plunge gently west-southwest.

Similar calcite veins and folds occur in gently NW-dipping beds of the Macumber Formation at Aulds Cove, where the limestone is overlain by siltstone and shale of the Mabou Group. The unexposed contact is, therefore, the Ainslie Detachment of Lynch and Giles (1995), who attributed the absence of the evaporitic Windsor Group to movement on the detachment surface. The isoclinally folded calc-mylonite that they describe from the contact suggests broadly NW-directed movement. In the Macumber Formation limestone, the calcite veins dip steeply north and west while the fold axes are subhorizontal and trend NE-SW (Fig. 8b), consistent with broadly NW-SE extension.

Southwest of Antigonish, where the Macumber Formation 


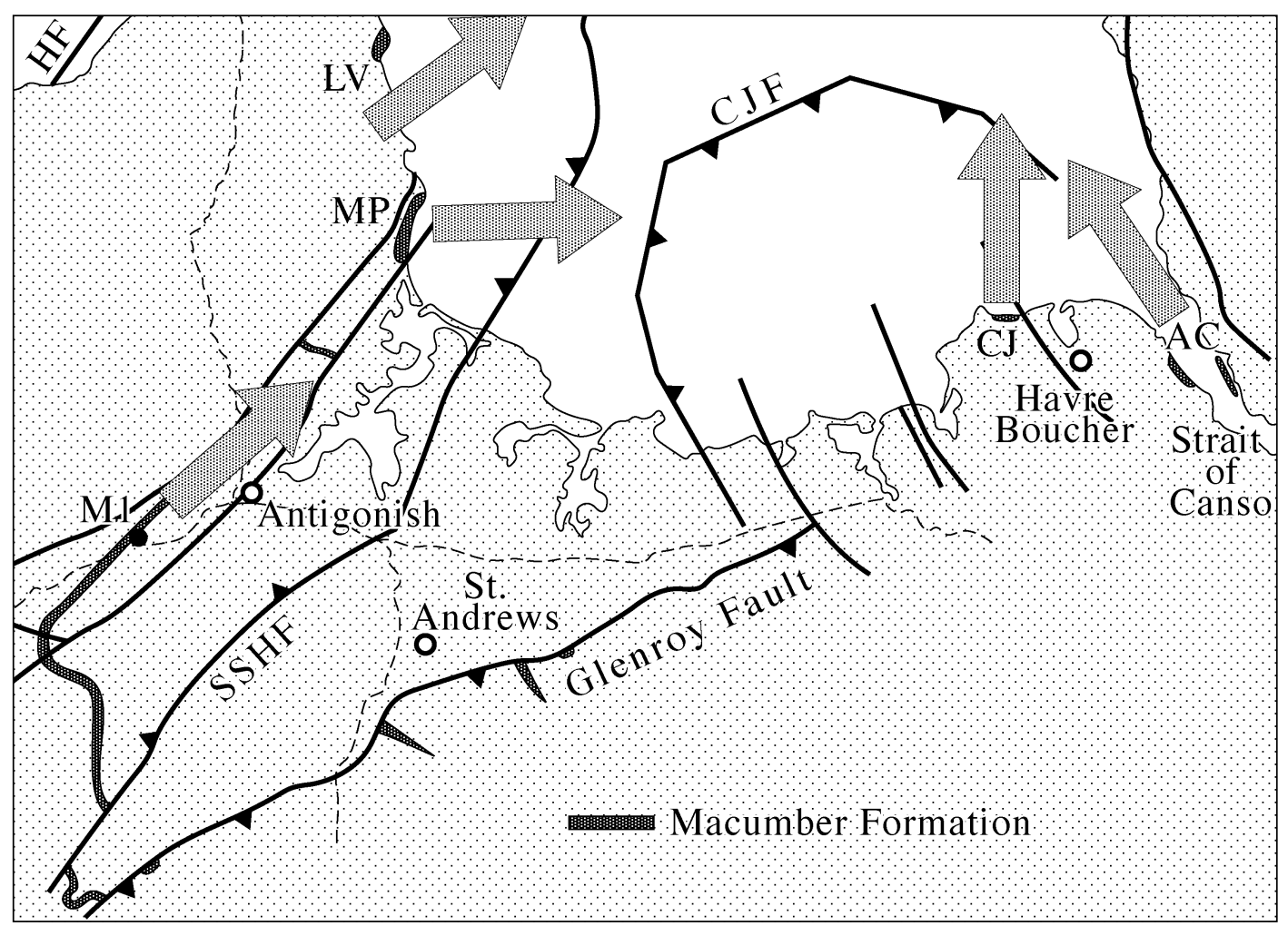

FIG. 9 Summary of general direction of movement and/or extension based on orientation of fold axes and/or calcite veins at localities exposing limestone of the Macumber Formation ( $L V=$ Lakevale, $M P=$ MacIsaacs Point, $M 1=$ western basin margin, $C J=$ Cape Jack, AC =Aulds Cove).

occurs along the western basin margin, calcite veins similar to those at Cape Jack and Aulds Cove occur in outcrops beside the Canadian National railroad (site M1, Fig. 9). Here the limestone dips moderately south and the veins dip steeply north-northeast (Fig. 8c).

\section{STRUCTURAL INTERPRETATION}

Figure 9 summarizes directional evidence for movement and/ or extension at localities exposing limestone of the Macumber Formation. At MacIsaacs Point and Lakevale, large-scale folds interpreted as being post-depositional slump structures verge eastward into St. Georges Bay, whereas the orientation of smallscale normal faults and boudinaged beds at Lakevale is consistent with NE-SW extension. A similar extension direction is recorded in the orientation of calcite fractures at the western basin margin, whereas those exposed at Cape Jack and Aulds Cove record N-S to NW-SE extension. In all cases, however, the structures imply a component of extension towards the centre of the basin beneath St. Georges Bay.

The presence of calcite veins and previously folded layering in the corroded limestone clasts of the Macumber Formation breccia further suggests that, although clearly post-depositional, many of the small-scale structures in the Macumber Formation limestone were produced prior to the deposition of the overlying evaporitic sequence of the Windsor Group and, hence, are Viséan in age.

\section{DISCUSSION}

Deformation of the Macumber Formation limestone throughout the Antigonish Basin is consistent with low-angle gravitational movement towards the basin centre. The nature and location of this deformation clearly invites its association with the Ainslie Detachment, which Lynch and Giles (1995) placed along the immediately overlying carbonate-evaporite interface. The kinematics and timing of the deformation, however, argue against such a correlation.

According to Lynch and Giles (1995), the Ainslie Detachment is a regional, broadly west-vergent structure that can be traced across much of northern Nova Scotia and western Cape Breton Island. It is held responsible for the local stratigraphic omission of the Windsor Group and is considered to have developed in the late Namurian to early Westphalian. The structures in the Macumber Formation, on the other hand, appear to record within-basin deformation in which extension was directed toward the basin centre. Structures developed along the western margin of the basin further suggest that deformation occurred, not as a result of west-vergent Namurian-Westphalian detachment, but in response to east-vergent gravitational sliding during the midViséan. Although neither precluding the existence of the Ainslie Detachment nor negating the timing of its movement, these relations rule out movement on the detachment surface as the cause of deformation and raise the possibility that similar structures developed in the Macumber Formation in other Carboniferous 
basins may likewise be unrelated to movement on the Ainslie Detachment.

In the case of the Antigonish Basin, slumping of the Macumber Formation toward the basin centre is most easily attributed to movement on the basin-bounding faults (Fig. 1). Following the deposition of the Macumber Formation, significant movement on these faults must have occurred in order to accommodate the subsequent increase in thickness of the basin fill. During basinwide deposition of the Macumber Formation, the decametre thickness of which records very shallow water deposition, the floor of the Antigonish Basin can have had little or no topography. Yet the remaining formations of the Windsor Group exceed $1.5 \mathrm{~km}$ in thickness. Movement compatible with such subsidence can be seen along the Glenroy Fault, which juxtaposes the Macumber Formation limestone to the south against the uppermost (Hood Island) formation of the Windsor Group to the north, a throw in excess of $1 \mathrm{~km}$. Such movement is likely to have caused local instability of the basin floor and, coupled with similar movement on other basin-bounding faults, may have provided the impetus for repeated post-depositional slumping of the Macumber Formation down-slope toward the basin centre.

\section{CONCLUSIONS}

A variety of structures occurs in the Viséan Macumber Formation of the Antigonish Basin immediately beneath the basal carbonate-evaporite contact of the Windsor Group, an interface along which significant low-angle west-directed extensional faulting (Ainslie Detachment) has been proposed for the late Namurian-early Westphalian (Lynch and Giles 1995). The structures include recumbent folds, boudins, small-scale normal faults, and calcite veins, from which the timing of deformation and the direction of extension can be determined. The occurrence of veins and folds in clasts within folded zones of depositional breccia show that deformation was repeated and closely followed deposition of the Macumber Formation in the Viséan. Locally east-vergent fold asymmetries and the orientation of calcite veins and small-scale normal faults further require extension to have converged on the centre of the basin located in St. Georges Bay. These results argue against post-Windsor movement on the Ainslie Detachment as the cause of deformation and suggest, instead, an origin through earlier within-basin slumping. Renewed movement on basinbounding faults required to accommodate the increase in basin fill thickness following deposition of the Macumber Formation may have provided the necessary instability.

\section{ACKNOWLEDGEMENTS}

Funding was provided by an Ohio University Graduate Assistantship to Thomas and by grants from the Program of North American Mobility in Higher Education to Nance and the Natural Sciences Engineering Research Council to Murphy. Comments by journal reviewers Nick Culshaw and Paul Williams greatly improved an earlier version of the manuscript.

\section{REFERENCES}

Boenner, R.C. 1980. Note on the revised stratigraphy of the Lower Carboniferous Windsor Group, Crystal Cliffs section, Antigonish County, Nova Scotia. In Mineral Resources Division, Report of Activities 1979. Nova Scotia Department of Mines and Energy, Report 80-1, pp. 137-145.

Boenner, R.C., \& Giles, P.S. 1982. Geological map of the Antigonish Basin, Nova Scotia. Nova Scotia Department of Mines and Energy, scale 1: 50,000.

Boenner, R.C., \& GiLes, P.S. 1993. Geology of the Antigonish Basin, Antigonish Country, Nova Scotia. Nova Scotia Department of Natural Resources, Mines and Energy Branches, Memoir 8, $109 \mathrm{p}$.

BRADLEY, D.C. 1982. Subsidence in late Paleozoic basins in the northern Appalachians. Tectonics, 1, pp. 107-123.

Clifton, H.E. 1967. Solution-collapse and cavity filling in the Windsor Group, Nova Scotia, Canada. Geological Society of America Bulletin, 78, pp. 819-832.

Durling, P., Harvey, P., \& Howells, K. 1995a. Geophysical evidence for thrust faulting in the Carboniferous Antigonish-Mabou Subbasin, Nova Scotia. Atlantic Geology, 31, pp. 183-196.

Durling, P., Harvey, P., \& Howells, K. 1995b. The nearsurface geology of St. Georges Bay, Nova Scotia: implications for the Hollow Fault. Canadian Journal of Earth Sciences, 32, pp. 603-613.

Fyson, W.K. 1967. Gravity sliding and cross folding in Carboniferous rocks, Nova Scotia. American Journal of Science, 265, pp. 1-11.

Geldsetzer, H.H.J. 1978. The Windsor Group in Atlantic Canada - an update. In Report of Activities, Part C. Geological Survey of Canada, Paper 78-1C, pp. 43-48.

GILES, P.S. 1981. Major transgressive-regressive cycle in middle to Late Viséan rocks of Nova Scotia. Nova Scotia Department of Mines and Energy, Paper 81-2.

Hamblin, A.P., \& RUST, B.R. 1989. Tectono-sedimentary analysis of alternate polarity half-graben basin-fill successions: Late Devonian-Early Carboniferous Horton Group, Cape Breton Island, Nova Scotia. Basin Research, 2, pp. 239-255.

Keppie, J.D., Giles, P.S., \& Boehner, R.C. 1978. Some Middle Devonian to Lower Carboniferous rocks of Cape George, Nova Scotia. Nova Scotia Department of Mines, Paper 78-4, 37 p.

Lavoie, D., \& Sangster, D.F. 1995. Origins and timing of basal Windsor carbonate breccias, Nova Scotia. In Current Research, Part D. Geological Survey of Canada, Paper 1995D, pp. 1-10.

LynCH, G., \& GILES, P.S. 1995. The Ainslie Detachment: a regional flat-lying extensional fault in the Carboniferous evaporitic Maritimes Basin of Nova Scotia, Canada. Canadian Journal of Earth Sciences, 33, pp. 169-181.

Lynch, G., \& Tremblay, C. 1994. Late Devonian-Carboniferous detachment faulting and extensional tectonics in western Cape Breton Island, Nova Scotia, Canada. Tectonophysics, 238, pp. 55-69.

Lynch, G., Keller, J.V.A., \& Giles, P.S. 1998. Influence of the 
Ainslie Detachment on the stratigraphy of the Maritimes Basin and mineralization in the Windsor Group of northern Nova Scotia, Canada. Economic Geology, 93, pp. 703-718.

McCutcheon, S.R., \& Robinson, P.T. 1987. Geological constraints on the genesis of the Maritimes Basin, Atlantic Canada. In Sedimentary Basins and Basin-Forming Mechanisms. Edited by C. Beaumont and A.J. Tankard. Canadian Society of Petroleum Geologists, Memoir 12, pp. 287-297.

Murphy, J.B., Keppie, J.D., \& Hynes, A.J. 1991. Geology of the Antigonish Highlands. Geological Survey of Canada, Paper 89-10, $114 \mathrm{p}$.

Ravenhurst, C., \& Zentilli, M. 1987. A model for the evolution of hot $\left(>200^{\circ} \mathrm{C}\right)$ overpressured brines under an evaporite seal: The Fundy/Magdalen Carboniferous Basin of Atlantic Canada and its associated $\mathrm{Pb}-\mathrm{Zn}$-Ba deposits. In Sedimentary Basins and Basin-Forming Mechanisms. Edited by C. Beaumont and A.J. Tankard. Canadian Society of Petroleum Geologists, Memoir 12, pp. 335-349.

Savard, M.M., Lynch, G., \& Fallara, F. 1996. Burial diagenesis model for the Macumber Formation on Cape Breton Island-implications for the tectonic evolution of the Windsor Group. Atlantic Geology, 32, pp.53-64.
Schenk, P.E. 1967. The Macumber Formation of the Maritime Provinces, Canada - a Mississippian analogue to Recent strandline carbonates of the Persian Gulf. Journal of Sedimentary Petrology, 37, pp. 365-376.

Schenk, P.E. 1984. Carbonate-sulphate relations in the Windsor Group - central Nova Scotia, Canada. In 9th International Congress of Carboniferous Stratigraphy and Geology, 1979. Compte Rendu, 3, pp. 143-162.

Stockmal, G.S., Colman-SAdd, S.P., Keen, C.E., O’Brien, S.J., \& Quinlan, G. 1986. Collision along an irregular margin: a regional plate tectonic interpretation of the Canadian Appalachians. Canadian Journal of Earth Sciences, 24, pp. 1098-1107.

Utting, J., Keppie, J.D., \& Giles, P.S. 1989. Palynology and age of the Lower Carboniferous Horton Group. In Contributions to Canadian Paleontology. Geological Survey of Canada, Bulletin 396, pp. 117-143.

Editorial responsibility: Sandra M. Barr 